\section{Producing a Grafted and a Non-Grafted Tomato Plant from the Same Seedling}

\author{
Hanna Y. Hanna ${ }^{1}$
}

AdDitional INDEX wORDs. Solanum lycopersicum, propagation methods, cultivars, stump sprouts, reducing costs

SUMMARY. Growing grafted hybrid tomato (Solanum lycopersicum) cultivars in greenhouse operations is gaining popularity worldwide. The costs of producing grafted plants remain a deterrent to the smaller producer. After removing plant tops to use as scions for grafting tomato plants, the stumps that have well-developed root systems and cotyledon leaves are usually discarded with the root media and containers. If productive plants can be produced from sprouts on the stumps, they can be used as non-grafted hybrids at the same farm or sold to other growers for income to defray part of the grafting costs. A 2-year greenhouse study examined the effects of three propagation methods and three tomato cultivars on plant yield and related traits. Seedling, grafted, and stump sprout plants of the hybrid cultivars Geronimo, Quest, and Starbuck were used in this study. Plants grafted on 'Maxifort' rootstock had greater stem diameter $(P<0.0001)$ below the first and third clusters than the seedling or stump sprout plants. The seedling plants had greater stem diameter than stump sprout plants below both clusters. During the first 3 weeks of harvest, seedling plants produced greater yields $(P<0.0001)$ than grafted or stump sprout plants and the differences were cultivar related. 'Quest' was the only cultivar that produced similar yields ( $2.8 \mathrm{vs} .2 .3 \mathrm{lb})$ as a seedling or a grafted plant during the first 3 weeks of harvest. Tomato plants propagated by all three methods produced similar yields and fruit weight in the remaining 16 weeks of harvest. Cultivars had no significant effect on yield during the first 3 weeks of harvest $(P>0.05)$, but their yields were significantly different during the remaining 16 weeks of harvest $(P<0.0001)$. The apparent reason for yield advantages of the seedling plants during the first 3 weeks of harvest was the uninterrupted growth during the seedling stage. Propagation method had no specific influence on fruit quality attributes. On the bases of this study, producing productive tomato plants from stump sprouts is a feasible cultural technique that can reduce losses associated with plants used in grafting. It also allows the repeated use of the soilless media and the seedling containers. The produced plants can generate substantial income for businesses that graft a significant number of tomato seedlings. For this cultural method to work, grafting should be timed to allow the stump sprout plants to grow for at least 5 weeks before planting in the grow bags. This practice is normally followed in producing transplants from seeds.

G rafting tomato plants is an old cultural technique that has been practiced since the early 1900s in Japan, South Korea, and other Asian and Middle Eastern countries (Kubota et al., 2008). The use of grafted plants was not common in North America up until late in the last century except in home gardens and by small organic tomato growers in the southern United States (King et al., 2008). Surveys conducted in 2006

Louisiana State University Agricultural Center, Red River Research Station, 262 Research Station Drive, Bossier City, LA 71112

Approved for publication by the Director of Louisiana Agriculture Experiment Station as Manuscript No. 2011-253-6573. The mention of a trademark, proprietary product, or vendor does not constitute a guarantee or warranty of the product by the Louisiana State University Agricultural Center and does not imply its approval to the exclusion of other products or vendors that also may be suitable.

${ }^{1}$ Corresponding author. E-mail: hhanna@agcenter. lsu.edu. showed the number of grafted seedlings in North America was over 40 million indicating a change of this trend (Jung et al., 2005; Kubota et al., 2008). Tomato growers want to grow grafted plants to control soil-borne diseases, increase yield, and improve plant adaptation to less than optimum environmental conditions (Bletsos et al., 2003; Giles, 2011; King et al., 2008; Louws et al., 2010; Schwarz et al., 2010).

Producing grafted tomato plants is costly because of intensive labor input for propagation, optimizing the environmental conditions for healing the graft, longer periods needed for producing the transplants, and the additional costs of the rootstock (Rivard et al., 2010). The high costs often discourage potential growers even with the additional benefits of increased yield and reduction of pest control costs. Production of double-stemmed grafted plants was suggested to reduce the expenses needed to purchase the grafted plants (Jung et al., 2005). Semiautomated or fully automated grafting robots were also invented to minimize labor cost for grafting vegetables (Kurata, 1994).

The practice of grafting tomato plants leads to discarding the stumps of the scion cultivar after removing the tops for grafting (Snyder, 2011). In most cases, the stumps are the remains of costly hybrid cultivars that were planted in multicell trays filled with commercial soilless mixtures (Rivard et al., 2010). The stumps have welldeveloped root systems that supported the scion plants for $\approx 3$ weeks before cutting the tops for grafting (Black et al., 2003). If productive plants can be generated on the stumps, they can be used at the same farm or sold to other growers as non-grafted hybrids for returns that can defray part of the grafting costs.

The objectives of this study were to evaluate the effects of propagating three tomato cultivars as seedling, grafted, and stump sprout plants on yield and related traits and to determine if the outcome is cultivar related.

\section{Materials and methods}

Studies were conducted in 2010 and 2011 in a $30 \times 96-\mathrm{ft}$ doublepolyethylene greenhouse used to grow 600 tomato plants in 300 polyethylene bags, at Louisiana State University Agricultural Center in Bossier City. In every study, tomato plants were grown in 5gal upright grow bags filled to 2 inches from the top with perlite, using a run to waste production system in which nutrient runoff was not recycled (Snyder,

\begin{tabular}{llll}
\hline $\begin{array}{l}\text { Units } \\
\text { To convert U.S. to SI, } \\
\text { multiply by }\end{array}$ & U.S. unit & SI unit & $\begin{array}{l}\text { To convert SI to U.S., } \\
\text { multiply by }\end{array}$ \\
\hline 0.3048 & $\mathrm{ft}$ & $\mathrm{m}$ & 3.2808 \\
2.54 & inch(es) & $\mathrm{cm}$ & 0.3937 \\
0.4536 & $\mathrm{lb}$ & $\mathrm{kg}$ & 2.2046 \\
28.3495 & $\mathrm{oz}$ & $\mathrm{g}$ & 0.0353 \\
1 & $\mathrm{ppm}$ & $\mathrm{mg} \cdot \mathrm{L}^{-1}$ & 1
\end{tabular}


2001). The perlite in each bag was disinfected and used for the duration of the study (Hanna, 2010).

Seeds from the hybrid tomato cultivars Geronimo, Quest, and Starbuck were planted around the third week of November in plastic trays with 38 cells. Each cell measured 2.2 inches in diameter and 2.5 inches in depth (Growing System, Milwaukee, WI). The trays were filled with soilless mix (Pro-Mix BX; Premier Horticulture, Quakertown, PA), and the seedlings were grown for 5 weeks before planting in the grow bags. Additional seedlings from all cultivars and the rootstock 'Maxifort' were grown in the seedling trays for 3 weeks (Leonardi and Romano, 2004) before grafting in early December. All three cultivars were grafted using the tube grafting technique described by McAvoy (2005). The 3-week-old 'Maxifort' seedlings were cut at an angle below the cotyledon leaves and the tops were discarded. 'Geronimo', 'Quest', and 'Starbuck' seedlings of the same age were cut at similar angle above the cotyledon leaves and the tops (scions) were grafted onto the rootstock bottoms. The graft union was held by a silicon tube (Bato Plastics, Zevenbergen, The Netherlands) that holds the scion and rootstock together in firm contact. Each silicon tube has a slit that allows the tube to fall off as the graft union heals and expands in diameter (Black et al., 2003; Kubota et al., 2008). The grafted plants were protected from direct sun light in high humidity tunnels for 7-10 d and gradually acclimated to normal growing conditions for another 5-10 d before planting in the grow bags. The remaining stumps of all three cultivars were kept under the same growing conditions of the transplants from seeds to generate sprouts (new plants) from the auxiliary buds at the cotyledon leaves. One sprout was allowed to grow per stump for 2-3 weeks before transplanting in the grow bags.

All seedling, grafted, and stump sprout plants were transplanted into the grow bags $\approx 5$ weeks following sowing. Two transplants planted at a 3 -inch depth to cover the root ball and spaced 7 inches apart in each grow bag. Using the $\mathrm{V}$-shape method, plants were spaced 17 inches apart within the row and rows were spaced $3 \mathrm{ft}$ apart at the overhead supporting wire. The greenhouse had 10 rows of plants with north/south orientation. Other cultural practices consisted of standard recommendations for growing greenhouse tomatoes for fresh market production in Louisiana and Mississippi (Hanna, 2003; Snyder, 2001).

The experiment was a $3 \times 3$ factorial of propagation methods (seedling, grafted, and stump sprout plants) and cultivars (Geronimo, Quest, and Starbuck) in a randomized complete block design with three replications (plots) of eight plants. Stem diameter of all plants per plot was measured below the first and third fruit cluster using a caliper (Fraction+; Central Tools and Instruments, New York). Three to five ripe fruit having similar color and size were selected from each plot at midharvest in early May for fruit analysis. Fruit were placed in a food processor (Waring Commercial, Atlanta) after slicing to small wedges. The food processor was operated at high speed until all fruit tissue reached a liquid form (Morgan, 2001). About $0.3 \mathrm{~mL}$ of the mixed solution was placed onto the surface of a digital refractometer (Pal-1; Atago, Tokyo) and soluble solids concentration was recorded. Fruit potassium and sodium contents were determined using a Cardy ion meter (Horiba Instruments, Irvine, CA). Fruit $\mathrm{pH}$ was determined using a $\mathrm{pH}$ meter (IQ Scientific Instruments, San Diego).

Harvest was initiated in early March and ended in mid-July. Fruit was harvested at the pink ripening stage twice per week for 19 weeks. Small-size fruit and fruit with blossomend rot and other defects were removed (negligible number because most were removed during cluster pruning), and the remainder graded according to U.S. Department of Agriculture standards (USDA, 1997). Marketable yield was determined by weighing fruit graded medium or larger during the first 3 weeks and during the remaining 16 weeks of harvest to reflect the effects of the early growth interruption of grafted and stump sprout plants on yield.

Data were analyzed as a randomized complete block design with three replications, using the PROC MIXED procedure of SAS (version 9.2; SAS Institute, Cary, NC). Blocks (replications) nested within years were considered random, and propagation methods and cultivars were considered fixed. Levels of significance of the main effects and interactions in the analysis of variance table were determined with the F test. Mean separation of the main effects and interactions was conducted using the DIFF option of the least square means.

\section{Results and discussion}

Data are presented as the average of 2 years because by-year interaction effects on evaluated traits were not significant. Propagation methods and cultivars had significant effects on stem diameter below the first and third cluster, but their interaction effect was not significant (Table 1). The grafted plants produced greater stem diameter than the seedling plants or the stump sprout plants below both clusters. Previous reports indicated that the rootstocks and scions interact, to produce vigorous root system that enhances water and mineral uptake, leading to stronger grafted plants (Lee, 1994; White, 1963). Stump sprout plants produced the smallest stem diameter below both clusters as a result of late growth. The presence of the cotyledon leaves and a well-developed root system on the stumps did not accelerate sprouts growth to achieve similar stem diameter to the seedling plants. 'Geronimo' produced plants with greater stem diameter than any of the other two cultivars below both clusters (Table 1).

Propagation method had significant effects on tomato marketable yield during the first 3 weeks of harvest, but had no effects on the marketable yield during the remaining 16 weeks of har vest. Plants propagated by all three methods produced fruit with similar weight (Table 2). Cultivars had no significant effect on marketable yield during the first 3 weeks of harvest, but marketable yields and fruit weight were significantly different during the remaining 16 weeks of harvest. After the first 3 weeks of harvest, 'Geronimo' produced significantly greater yields than 'Quest' or 'Starbuck'. This is similar to previous studies where 'Geronimo' produced greater marketable yields than 'Quest' (Hanna, 2009). Propagation method $\times$ cultivar interaction for yield was significant during the first 3 weeks of harvest (Table 2). Regardless of the cultivar, seedling plants produced significantly greater marketable yields than stump sprout plants during the first 3 weeks of harvest (Table 3). Seedling plants also produced significantly greater marketable yields than grafted plants during the same period except 'Quest' (Table 3). 
Table 1. Analysis of variance and mean separation by least square means of tomato stem diameter below first and third clusters in 2010 and 2011 as related to treatment effect in a $30 \times 96-\mathrm{ft}(9.1 \times 29.3-\mathrm{m})$ greenhouse at Louisiana State University Agricultural Center, Bossier City.

\begin{tabular}{|c|c|c|}
\hline \multirow[b]{2}{*}{ Treatment } & \multicolumn{2}{|c|}{ Avg stem diam over 2 years (inches) ${ }^{\mathrm{z}}$} \\
\hline & Below first cluster & Below third cluster \\
\hline \multicolumn{3}{|l|}{ Propagation method } \\
\hline Grafted & $0.57 \mathrm{a}^{\mathrm{y}}$ & $0.63 \mathrm{a}$ \\
\hline Seedling & $0.54 \mathrm{~b}$ & $0.62 \mathrm{~b}$ \\
\hline Stump sprout & $0.39 \mathrm{c}$ & $0.59 \mathrm{c}$ \\
\hline \multicolumn{3}{|l|}{ Cultivar } \\
\hline Geronimo & $0.51 \mathrm{a}$ & $0.63 \mathrm{a}$ \\
\hline Quest & $0.50 \mathrm{~b}$ & $0.60 \mathrm{~b}$ \\
\hline Starbuck & $0.49 \mathrm{~b}$ & $0.61 \mathrm{~b}$ \\
\hline & \multicolumn{2}{|c|}{$P>\mathrm{F}$} \\
\hline Propagation method $(\mathrm{M})$ & $<0.0001$ & $<0.0001$ \\
\hline Cultivar (C) & 0.0004 & $<0.0001$ \\
\hline $\mathrm{M} \times \mathrm{C}$ & 0.6710 & 0.0779 \\
\hline
\end{tabular}

${ }^{2} 1$ inch $=2.54 \mathrm{~cm}$.

${ }^{y}$ For each propagation method and cultivar, means within columns followed by the same letter are not significantly different at $P \leq 0.05$ by least square means.

Table 2. Mean separation by least square means and analysis of variance for tomato marketable yield and fruit weight in 2010 and 2011 as related to treatment effect in a $30 \times 96-\mathrm{ft}(9.1 \times 29.3-\mathrm{m})$ greenhouse at Louisiana State University Agricultural Center, Bossier City.

\begin{tabular}{|c|c|c|c|}
\hline \multirow[b]{2}{*}{ Treatment } & \multicolumn{3}{|c|}{ Avg tomato yield over 2 years $(1 \mathrm{~b} / \text { plant })^{\mathrm{z}}$} \\
\hline & First $3 w^{\mathbf{y}}$ & Next $16 w^{x}$ & $\operatorname{Avg}$ fruit wt $(o z)^{\mathrm{w}}$ \\
\hline \multicolumn{4}{|l|}{ Propagation method } \\
\hline Grafted & & $26.5 \mathrm{a}^{\mathrm{v}}$ & $8.0 \mathrm{a}$ \\
\hline Seedling & & $25.5 \mathrm{a}$ & $7.8 \mathrm{a}$ \\
\hline Stump sprout & & $25.5 \mathrm{a}$ & $7.9 \mathrm{a}$ \\
\hline \multicolumn{4}{|l|}{ Cultivar } \\
\hline Geronimo & & $29.2 \mathrm{a}$ & $8.2 \mathrm{a}$ \\
\hline Quest & & $23.3 \mathrm{~b}$ & $7.5 \mathrm{~b}$ \\
\hline Starbuck & & $\begin{array}{r}25.1 \mathrm{~b} \\
\quad P>\mathrm{F}\end{array}$ & $8.0 \mathrm{a}$ \\
\hline Propagation method $(\mathrm{M})$ & $<0.0001$ & 0.4182 & 0.3461 \\
\hline Cultivar $(\mathrm{C})$ & 0.0783 & $<0.0001$ & $<0.0001$ \\
\hline $\mathrm{M} \times \mathrm{C}$ & 0.0059 & 0.2285 & 0.3582 \\
\hline
\end{tabular}

${ }^{\mathrm{z}} 1 \mathrm{lb}=0.4536 \mathrm{~kg}$.

${ }^{y}$ Marketable yield of fruit graded medium or larger in the first 3 weeks of the harvest season (March to July). ${ }^{x}$ Marketable yield of fruit graded medium or larger during the remaining 16 weeks of the harvest season.

${ }^{\mathrm{w}} \mathrm{loz}=28.3495 \mathrm{~g}$

"For each propagation method and cultivar, means within columns followed by the same letter are not significantly different at $P \leq 0.05$ by least square means

Table 3. Interaction effects of propagation methods and tomato cultivars on marketable yield during the first 3 weeks of harvest in a $30 \times 96-\mathrm{ft}(9.1 \times 29.3-\mathrm{m})$ greenhouse in 2010 and 2011 at Louisiana State University Agricultural Center, Bossier City.

\begin{tabular}{llcc}
\hline & \multicolumn{3}{c}{ Avg marketable yield over 2 years (1b/plant) ${ }^{\mathrm{z}}$} \\
\cline { 2 - 4 } Cultivar & \multicolumn{3}{c}{ Propagation method } \\
\hline Grafted & Seedling & Stump sprout \\
Geronimo & $2.2 \mathrm{~A} \mathrm{~b}^{\mathrm{y}}$ & $3.1 \mathrm{~A} \mathrm{~B} \mathrm{a}$ & $0.1 \mathrm{~B} \mathrm{c}$ \\
Quest & $2.3 \mathrm{~A} \mathrm{a}$ & $2.8 \mathrm{~B} \mathrm{a}$ & $0.8 \mathrm{~A} \mathrm{~b}$ \\
Starbuck & $2.5 \mathrm{~A} \mathrm{~b}$ & $3.6 \mathrm{~A} \mathrm{a}$ & $0.3 \mathrm{~B} \mathrm{c}$ \\
\hline
\end{tabular}

\section{${ }^{\mathrm{z}} \mathrm{l} \mathrm{lb}=0.4536 \mathrm{~kg}$.}

${ }^{y}$ For each cultivar, means within columns followed by the same upper case letter are not significantly different at $P \leq 0.05$ by least square means. For each propagation method, means within rows followed by the same lower case letter are not significantly different at $P \leq 0.05$ by least square means.
These differences indicate that the uninterrupted growth of the seedling plants for 5 weeks before planting in the grow bags contributed to greater yields during the first 3 weeks of harvest and the differences were cultivar related. The less productivity of stump sprout plants during the first 3 weeks of harvest can be explained by the fact that they were 3 weeks late in growth than the seedling plants. Previous work indicates that greenhouse tomato seedlings should be grown for at least 5 weeks before transplanting into the grow bags (Hanna, 2009). Regardless of the fast growth of the grafted plants, they were less productive during the first 3 weeks of harvest than the seedling plants except 'Quest'. The rapid vegetative growth of the grafted plants resulted in greater stem diameter below the first and third clusters than the seedling plants but not greater yields during the first 3 weeks or the remaining 16 weeks of harvest. Plants were grafted 3 weeks after planting the seeds and the grafted plants went through a period of healing before resuming normal growth. During that time, the seedling plants continued normal growth without interruption. The delayed regrowth of grafted plants may have contributed to their lack of yield advantage even though vegetative growth was faster.

Fruit analysis indicated that stump sprout plants produced fruit with higher sodium content and soluble solid concentrations than grafted plants. 'Quest' produced fruit with higher sodium contents than the other two cultivars. 'Starbuck' produced fruit with higher soluble solids concentration than 'Geronimo' but similar to 'Quest' (Table 4). Davis et al. (2008) indicated that grafting can affect various quality aspects of vegetables. Although propagation methods and cultivars had no significant effects on fruit potassium content, their interactions were significant (Table 4). Interaction effects indicated that 'Geronimo' and 'Starbuck' propagated by all three methods and all cultivars propagated by the seedling method produced fruit with similar potassium content (Table 5). In general, fruit analysis was not suggestive of specific quality associated with any propagation method. Previous work indicated that understanding the impact of grafting on vegetable fruit quality is far from being completed (Rouphael et al., 2010). 
Table 4. Analysis of variance and mean separation by least square means for tomato fruit potassium, sodium, $\mathrm{pH}$, and soluble solid concentration as related to three propagation methods and three cultivars planted in a $30 \times 96-\mathrm{ft}(9.1 \times$ 29.3-m) greenhouse in 2010 and 2011 at Louisiana State University Agricultural Center, Bossier City.

\begin{tabular}{|c|c|c|c|c|}
\hline \multirow[b]{2}{*}{ Treatment } & \multicolumn{4}{|c|}{ Tomato fruit analyses ${ }^{\mathrm{z}}$} \\
\hline & $\begin{array}{l}\text { Potassium } \\
(\mathrm{ppm})^{\mathrm{y}}\end{array}$ & $\begin{array}{c}\text { Sodium } \\
(\mathrm{ppm})\end{array}$ & $\mathrm{pH}$ & $\begin{array}{c}\text { Soluble solids } \\
\text { concn (\%) }\end{array}$ \\
\hline \multicolumn{5}{|l|}{ Propagation method } \\
\hline Grafted & & $30.6 b^{x}$ & $4.52 \mathrm{a}$ & $5.32 \mathrm{~b}$ \\
\hline Seedling & & $39.3 \mathrm{a}$ & $4.51 \mathrm{a}$ & $5.56 \mathrm{ab}$ \\
\hline Stump's sprout & & $39.5 \mathrm{a}$ & $4.52 \mathrm{a}$ & $5.75 \mathrm{a}$ \\
\hline \multicolumn{5}{|l|}{ Cultivar } \\
\hline Geronimo & & $34.9 \mathrm{~b}$ & $4.53 \mathrm{a}$ & $5.38 \mathrm{~b}$ \\
\hline Quest & & 39.8 a & $4.49 \mathrm{a}$ & $5.53 \mathrm{a}$ \\
\hline Starbuck & \multicolumn{4}{|c|}{$P>\mathrm{F}$} \\
\hline Propagation method (M) & 0.1240 & $<0.0001$ & 0.8033 & 0.0265 \\
\hline Cultivar $(\mathrm{C})$ & 0.1175 & 0.0184 & 0.3247 & 0.1135 \\
\hline $\mathrm{M} \times \mathrm{C}$ & 0.0305 & 0.1789 & 0.3247 & 0.1983 \\
\hline
\end{tabular}

Table 5. Interaction effects of propagation method and tomato cultivar on fruit potassium content in a $30 \times 96-\mathrm{ft}(9.1 \times 29.3-\mathrm{m})$ greenhouse in 2010 and 2011 at Louisiana State University Agricultural Center, Bossier City.

\begin{tabular}{lccc}
\hline & \multicolumn{3}{c}{ Avg fruit potassium over 2 years (ppm $)^{\mathrm{z}}$} \\
\cline { 2 - 4 } Cultivar & Grafted plants & Seedling plants & Stump sprout plants \\
\cline { 2 - 4 } Geronimo & $1900 \mathrm{~B} \mathrm{a}^{\mathrm{y}}$ & $1867 \mathrm{~A} \mathrm{a}$ & $1883 \mathrm{~A} \mathrm{~B} \mathrm{a}$ \\
Quest & $2050 \mathrm{~A} \mathrm{a}$ & $1967 \mathrm{~A} \mathrm{a}$ & $1833 \mathrm{~B} \mathrm{~b}$ \\
Starbuck & $1917 \mathrm{~B} \mathrm{a}$ & $1917 \mathrm{~A} \mathrm{a}$ & $1950 \mathrm{~A} \mathrm{a}$ \\
\hline
\end{tabular}

${ }^{2} 1 \mathrm{ppm}=1 \mathrm{mg} \cdot \mathrm{L}^{-1}$.

'For each cultivar, means within columns followed by the same upper case letter are not significantly different at $P \leq$ 0.05 by least square means. For each propagation method, means within rows followed by the same lower case letter are not significantly different at $P \leq 0.05$ by least square means.

\section{Conclusions}

Using grafted tomato plants is gaining popularity in North American greenhouse tomato operations. Plant tops of good hybrid cultivars are used as scions to produce the grafted plants leaving the stumps to be discarded. In most cases, the stumps are left with the cotyledon leaves and a root system that supported the scions before grafting. Producing grafted plants from hybrid tomato cultivars is costly. The expenses include the price of seeds, labor wages, root media, seedling containers, feeding nutrients, and costs to optimize the growing conditions for a longer seedling stage.

This study indicates that producing productive plants from the stump sprouts is feasible and can be used to defray parts of the costs to produce the grafted plants. Both plants grown from mixtures. The grafting process should be timed to allow both the grafted and stump sprout plants to grow for at least 5 weeks before planting in the grow bags or sold commercially. Surveys conducted in 2006 revealed that the number of grafted seedlings in North America exceeded 40 million resulting in similar number of discarded stumps. Tomato plants produced from the stumps can be sold at market prices to generate substantial income for graft-producing businesses.

\section{Literature cited}

Black, L.L., D.L. Wu, J.F. Wang, T. Kalb, D. Abbass, and J.H. Chen. 2003. Grafting tomatoes for production in the hot-wet season. International cooperators guide. Asian Veg. Res. Dev. Ctr. Publ. 03-551.

Bletsos, F., C. Thanassoulopoulos, and D. Roupakias. 2003. Effect of grafting on growth, yield, and verticillium wilt of eggplant. HortScience 38:183-186.

Davis, A.R., P.P. Veazie, R. Hassell, A. Levi, S.R. King, and X. Zhang. 2008. Grafting effects on vegetable quality. HortScience 43:1670-1672.

Giles, F. 2011. Gaining Grafting Knowledge. In the absence of methyl bromide, grafting might be one means of fighting tomato diseases. 7 Oct. 2011. <http:// www.growingproduce.com/production/ cropprotection/?storyid $=181>$.

Hanna, H.Y. 2003. Greenhouse Tomato Manual. 7 Oct. 2011. <http://www. lsuagcenter.com / en/lawngarden / commercial_horticulture/greenhouse_ production/Greenhouse+Tomato+ Production+Manual.htm>.

Hanna, H.Y. 2009. Influence of cultivar, growing media, and cluster pruning on greenhouse tomato yield and fruit quality. HortTechnology 19:395-399.

Hanna, H.Y. 2010. Reducing time and expense to recycle perlite for repeat use in greenhouse tomato operations. HortTechnology 20:746-750.

Jung, K.Y., Y.J. Park, and J.M. Lee. 2005. Production of double-stemmed grafted tomato plug seedlings. HortScience 40: 1056 (abstr.).

King, S.R., A.R. Davis, W. Liu, and A. Levi. 2008. Grafting for disease resistance. HortScience 43:1673-1676.

Kubota, C., M.A. McClure, N. KokalisBurelle, M.G. Bausher, and E.N. Rosskopf. 2008. Vegetable grafting: History, use, and current technology status in North America. HortScience 43:1664-1669. 


\section{Research Reports}

Kurata, K. 1994. Cultivation of grafted vegetables II. Development of grafting robots in Japan. HortScience 29:240-244.

Lee, J.M. 1994. Cultivation of grafted vegetables I. Current status, grafting methods, and benefits. HortScience 29:235-239.

Leonardi, C. and D. Romano. 2004. Recent issues on vegetable grafting. Acta Hort. 631:163-174.

Louws, F., C. Rivard, and C. Kubota. 2010. Grafting fruiting vegetables to manage soilborne pathogens, foliar pathogens, arthropods and weeds. Sci. Hort. 127:127-146.

McAvoy, R. 2005. Grafting Techniques For Greenhouse Tomatoes. 14 Nov.
2011. <http://www.hort.uconn.edu/ $\mathrm{ipm} /$ greenhs/htms/Tomgraft.htm $>$.

Morgan, L. 2001. Measuring fruit quality and fruit quality testing by grower. Tomato Mag. 5(4):12-15.

Rivard, C.L., O. Sydorovych, S. O'connell, M.M. Peet, and F.J. Louws. 2010. An economic analysis of two grafted tomato transplant production systems in the United States. HortTechnology 20:794-803.

Rouphael, Y., D. Schwarz, A. Krumbein, and G. Colla. 2010. Impact of grafting on product quality of fruit vegetables. Sci. Hort. 127:172-179.

Schwarz, D., Y. Rouphael, G. Colla, and J.H. Venema. 2010. Grafting as a tool to improve tolerance of vegetables to abiotic stresses: Thermal stress, water stress and organic pollutants. Sci. Hort. 127:162171.

Snyder, R.G. 2001. Greenhouse tomato handbook. Mississippi State Univ. Ext. Serv. Publ. 1828

Snyder, R.G. 2011. Greenhouse short course provides great education for tomato growers. Tomato Mag. 15(3):14-15.

U.S. Department of Agriculture. 1997. United States standards for grades for fresh tomatoes. U.S. Dept. Agr., Agr. Mkt. Serv. 7 CFR 51.

White, R.A.J. 1963. Grafted greenhouse tomatoes give heavier crops. N.Z. J. Agr. 106:247-248. 